\title{
Direct control of perennial weeds between crops - Implications for organic farming
}

\author{
Bo Melander*, Niels Holst, Ilse Ankjær Rasmussen, Preben Klarskov Hansen \\ Aarhus University, Faculty of Science and Technology, Department of Agroecology, Research Centre Flakkebjerg, DK-4200 Slagelse, Denmark
}

\section{A R T I C L E I N F O}

Article history:

Received 23 December 2011

Received in revised form

16 April 2012

Accepted 20 April 2012

\section{Keywords:}

Mechanical weed control

Cirsium arvense

Tussilago farfara

Elytrigia repens

Sonchus arvensis

\begin{abstract}
A B S T R A C T
Perennial weeds can be a major constraint to organic crop production and direct control actions applied between crops can then be necessary to reduce the problems. We conducted two experiments, one on a sandy loam and one on a sandy soil in Denmark, with the aim of studying the efficacy of different implement types and strategies. The treatments were employed against mixed stands of perennials after harvest of spring barley in two consecutive years. Time of treatment, cultivation depth and combinations of implements constituted the strategies. Treatment effects were evaluated in the growing season that followed the post-harvest treatments. In the one experiment, repeated tine cultivation caused an 80 $-90 \%$ annual reduction of the population of mainly Cirsium arvense. With treatments conducted in two consecutive years, the accumulated effects reached 99\% control. In the second experiment, power take-off driven implements with rotating weeding devices demonstrated similar control efficacies against a mixed stand composing C. arvense, Tussilago farfara, Elytrigia repens and Artemisia vulgaris. One pass was conducted a week after barley harvest followed by another pass 3 weeks later and ending the strategy with mouldboard ploughing in the succeeding spring. Grain yields did not differ among the treatments in the two experiments as a result of the generally high effectiveness exerted by the control strategies. Especially post-harvest control strategies based on rotating weed devices and mouldboard ploughing appear to be effective solutions against mixed stands of perennials on sandy soils but they do not comply with optimal nutrient management in organic cropping. Therefore, intensive autumn cultivation is only relevant where a perennial weed problem is uncontrollable by other means.
\end{abstract}

(c) 2012 Elsevier Ltd. All rights reserved.

\section{Introduction}

Perennial weeds pose considerable threat to crop productivity in organic cropping (Alrøe and Halberg, 2008; Turner et al., 2007). Crop yield and quality can be severely reduced by vigorous growth of perennials (e.g. Graglia et al., 2006; Melander, 1994) and heavy infestations can obstruct combining operations. The rhizomatous growth of some species (e.g. Elytrigia repens (L.) Desv. ex Nevski) may impede harvesting potato tubers and taproots of for example carrots, beetroot and parsnip. In Scandinavia, Cirsium arvense (L.) Scop, E. repens, Tussilago farfara L., Rumex crispus L. and Sonchus arvensis L. are particularly problematic in organic crops (Alrøe and Halberg, 2008; Melander et al., 2011; Salonen et al., 2011).

Several management options can be used against perennials, characterised by preventive measures (e.g. crop rotation, primary tillage), cultural methods (e.g. competitive varieties, improved crop

\footnotetext{
* Corresponding author. Tel.: +45 871581 98, +45 22283393 (mobile).

E-mail address: bo.melander@agrsci.dk (B. Melander).
}

nutrition) and direct control methods (e.g. inter-row hoeing, mowing and stubble cultivations) (Bond and Grundy, 2001; Rasmussen et al., 2006). Successful management usually requires input from all three management categories. Preventive and cultural methods are needed for balancing the cropping system to minimise gaps in which perennials may proliferate uncontrollably. However, cropping systems normally have to comply with many other interests, and situations that benefit perennials may easily occur. Then direct control methods are needed to control the weeds. Hand pulling $R$. crispus and $C$. arvense in the crop can be effective but is only feasible against small and limited stands (e.g. Zaller, 2004). Repeated inter-row hoeing may provide some control against S. arvensis and C. arvense (Graglia et al., 2006; Vanhala et al., 2006) while mechanical tools, such as weed harrows and finger weeders, are ineffective (Melander et al., 2005). Thermal methods defoliating perennials usually do not prevent re-sprouting from below-ground vegetative propagules (Ascard et al., 2007).

Tillage between crops is a well-known direct control option against perennials but its effectiveness may vary depending on species, weather and execution. Summer-fallowing is effective 
against the majority of perennial weed species but farm income is strongly challenged unless the fallow is applied on small areas (Donald, 1990; Turner et al., 2007; Vanhala et al., 2006). Postharvest cultivation strategies against $E$. repens can be effective (e.g. Brandsæter et al., 2011b; Håkansson, 1969) but leave the soil bare for long periods compromising optimal nutrient management (Melander et al., 2011). C. arvense is sensitive to deep tillage whilst the effect of shallow cultivations may vary (Brandsæter et al., 2011a, 2011b; Olsen, 2011). Brandsæter et al. (2010) and Tørresen et al. (2010) inferred that cultivations against perennials with low readiness of buds to sprout in late summer and autumn (e.g. S. arvensis) would have limited effect since innate bud dormancy makes exhaustion of the carbohydrate reserves in the roots impossible. Still, Anbari et al. (2011) and Vanhala et al. (2006) emphasise that fragmentation and deep burial of $S$. arvensis roots obtained by post-harvest tillage strategies should hamper $S$. arvensis growth markedly in subsequent crops. Very limited information is available on the non-chemical control of T. farfara in the scientific literature, and control strategies undertaken by the Danish Knowledge Centre for Agriculture have not led to any effective and reliable management strategy (Olsen, 2011).

Most studies with perennials have focussed on single species rather than mixed stands. However, perennial weed problems in organic crops may arise from several species occurring simultaneously. Pekrun and Claupein (2006) recommend that shallow cultivation shortly after harvest becomes a standard practise whenever perennials pose a threat to crop production. In general, however, detailed information on relevant strategies for mixed stands under field conditions is scarce. Clear recommendations on pertinent implement type, cultivation depth and treatment time are hard to communicate concisely to practise, except for the investigations on E. repens. We conducted two field experiments, each lasting 3 years, with the objective of clarifying these aspects of direct control of perennials between crops. In the first experiment, we investigated $C$. arvense and $S$. arvensis growth responses to timing of mouldboard ploughing and increasing stubble cultivation depth when applying an exhaustion strategy in which re-sprouted C. arvense shoots were controlled repeatedly. We hypothesised that i. mouldboard ploughing in spring is more effective than autumn ploughing, ii. increasing stubble cultivation depth to maximum $15 \mathrm{~cm}$ reduces $C$. arvense growth more than 5 or $10 \mathrm{~cm}$ depths. In the second experiment, the use of five different implements was studied against a mixed stand of perennial weed species, predominantly $T$. farfara, $C$. arvense, and E. repens. It was hypothesised that iii. strategies including rotating implements driven by power take-off (p.t.o.) from a tractor are more effective than strategies with tine or disc based implements, iv. autumn treatments supplemented by treatments in winter or spring increase effectiveness as compared with treatments applied in autumn only. Hypothesis i. was also tested in experiment 2.

\section{Materials and methods}

\subsection{Experiment 1}

The experimental area was a sandy loam located at Flakkebjerg Research Centre $\left(55^{\circ} 19^{\prime} 01.57^{\prime \prime} \mathrm{N}, 11^{\circ} 23^{\prime} 06.85^{\prime \prime} \mathrm{E}\right)$. The area had been cropped according to organic standards since 1996 and had a heavy infestation of $C$. arvense and minor patches of Rumex spp., $S$. arvensis, E. repens and T. farfara when the experiment was commenced in 2009. In autumn 2008, the area was divided into five density categories according to the distribution of $C$. arvense. Seven stubble cultivation treatments were then randomised within each density category giving a total of 35 treatments (Tables 1 and 2 ). Stubble cultivations were conducted every time $C$. arvense shoots had developed 2-5 leaves. This growth stage was decided because later growth stages might have been difficult to control effectively with the implements used and earlier growth stages would have limited the drainage of food reserves. The treatments were made in two consecutive seasons to estimate differences between years and accumulated effects. The goosefoot shares and winged shares used on the cultivators (Table 2) cut the soil over the entire working width. Gross plot size was $10 \times 15 \mathrm{~m}$ of which $5 \times 12.5 \mathrm{~m}$ was used for assessments of weed and crop growth. Each gross plot was surrounded by $5 \mathrm{~m}$ wide discards that were mown twice per growing season to prevent spreading of perennials between plots. Spring barley (variety Varberg in 2009 and variety mixtures in 2010 and 2011) was grown in all three years

Table 1

Stubble cultivations and mouldboard ploughing conducted in experiment 1 . For implement details see Table 2.

\begin{tabular}{|c|c|c|c|c|c|}
\hline \multirow{2}{*}{$\begin{array}{l}\text { Treatment } \\
\text { no. }\end{array}$} & \multirow[t]{2}{*}{ Implement } & \multirow[t]{2}{*}{ Working depth $(\mathrm{cm})$} & \multicolumn{2}{|l|}{ Treatment dates } & \multirow{2}{*}{$\begin{array}{l}\text { Mouldboard ploughing }^{\mathrm{a}} \\
\text { 2009/2010/2011 }\end{array}$} \\
\hline & & & 2009 & 2010 & \\
\hline 1 & No stubble cultivations & - & - & - & November \\
\hline 2 & No stubble cultivations & - & - & - & March \\
\hline 3 & Horsch Terrano 3 FX & All passes $4-5 \mathrm{~cm}$ & $\begin{array}{l}19 \text { Aug ( } 1 \text { pass) } \\
1 \text { Sep ( } 1 \text { pass) } \\
17 \text { Sep ( } 1 \text { pass }) \\
6 \text { Oct ( } 1 \text { pass })\end{array}$ & $\begin{array}{l}6 \text { Sep ( } 1 \text { pass) } \\
24 \text { Sep ( } 1 \text { pass) } \\
25 \text { Oct ( } 1 \text { pass) }\end{array}$ & November \\
\hline 4 & Horsch Terrano 3 FX & $\begin{array}{l}\text { First pass } 4-5 \mathrm{~cm} \text {, } \\
\text { subsequent passes } 10 \mathrm{~cm}\end{array}$ & $\begin{array}{l}19 \text { Aug ( } 1 \text { pass }) \\
1 \text { Sep ( } 1 \text { pass }) \\
17 \text { Sep ( } 1 \text { pass }) \\
6 \text { Oct ( } 1 \text { pass })\end{array}$ & $\begin{array}{l}6 \text { Sep ( } 1 \text { pass }) \\
24 \text { Sep ( } 2 \text { passes) } \\
25 \text { Oct ( } 1 \text { pass })\end{array}$ & November \\
\hline 5 & Horsch Terrano 3 FX & $\begin{array}{l}\text { First pass } 4-5 \mathrm{~cm} \text {, } \\
\text { subsequent passes } 15 \mathrm{~cm}\end{array}$ & $\begin{array}{l}19 \text { Aug ( } 1 \text { pass }) \\
1 \text { Sep ( } 1 \text { pass) } \\
17 \text { Sep ( } 1 \text { pass }) \\
6 \text { Oct ( } 1 \text { pass })\end{array}$ & $\begin{array}{l}6 \text { Sep ( } 1 \text { pass }) \\
24 \text { Sep ( } 2 \text { passes) } \\
25 \text { Oct ( } 1 \text { pass })\end{array}$ & November \\
\hline 6 & Vibro Flex & $\begin{array}{l}\text { First pass } 4-5 \mathrm{~cm} \text {, } \\
\text { subsequent passes } 10 \mathrm{~cm}\end{array}$ & $\begin{array}{l}19 \text { Aug ( } 1 \text { pass) } \\
1 \text { Sep ( } 1 \text { pass) } \\
17 \text { Sep ( } 1 \text { pass }) \\
6 \text { Oct ( } 1 \text { pass })\end{array}$ & $\begin{array}{l}6 \text { Sep ( } 1 \text { pass }) \\
24 \text { Sep ( } 2 \text { passes) } \\
25 \text { Oct ( } 1 \text { pass })\end{array}$ & November \\
\hline 7 & Vibro Flex & $\begin{array}{l}\text { First pass } 4-5 \mathrm{~cm} \text {, } \\
\text { subsequent passes } 10 \mathrm{~cm}\end{array}$ & $\begin{array}{l}19 \text { Aug ( } 1 \text { pass }) \\
1 \text { Sep ( } 1 \text { pass) } \\
17 \text { Sep ( } 1 \text { pass }) \\
6 \text { Oct ( } 1 \text { pass })\end{array}$ & $\begin{array}{l}6 \text { Sep ( } 1 \text { pass }) \\
24 \text { Sep ( } 2 \text { passes }) \\
25 \text { Oct ( } 1 \text { pass })\end{array}$ & March \\
\hline
\end{tabular}

\footnotetext{
a Ploughing to $20 \mathrm{~cm}$ soil depth.
} 
Table 2

Implement products and settings used in experiments 1 and 2 .

\begin{tabular}{|c|c|c|c|c|c|}
\hline Experiment & Trade mark & Tilling device & Working depth $(\mathrm{cm})$ & Rotations $\min ^{-1}$ & $\begin{array}{l}\text { Forward speed } \\
\left(\mathrm{km} \mathrm{h}^{-1}\right)\end{array}$ \\
\hline 1 & $\begin{array}{l}\text { Horsch } \\
\text { Terrano } 3 \text { FX }\end{array}$ & $\begin{array}{l}\text { Winged shares mounted on tines. } \\
\text { More information on: http://www.horsch2.com/ } \\
\text { en/products/soil-cultivation/cultivators/terrano-fx, } \\
\text { accessed 14th December } 2011\end{array}$ & See Table 1 & - & 10 \\
\hline 1 and 2 & Vibro Flex & $\begin{array}{l}\text { Goosefoot shares mounted on S-shaped vibrating tines. } \\
\text { More information on: http://www.kongskilde.com/en-GB/ } \\
\text { Soil/dbProducts/Product.htm\%3fproductid\%3d214, } \\
\text { accessed 14th December } 2011\end{array}$ & $\begin{array}{l}\text { See Table } 1 \text { for exp. } 1 \\
15 \text { in exp. } 2\end{array}$ & - & 10 \\
\hline 2 & $\begin{array}{l}\text { Howard } \\
\text { Rotavator }\end{array}$ & $\begin{array}{l}\text { P.t.o-driven rotary cultivator with "L"-shaped blades. } \\
\text { More information on: http://www.kongskilde.com/en-GB/ } \\
\text { Soil/dbProducts/Product.htm\%3fproductid\%3d363, } \\
\text { accessed 14th December } 2011\end{array}$ & 15 & 1000 & 2.7 \\
\hline 2 & Dynadrive & $\begin{array}{l}\text { Friction spade rotor tiller with straight tines entering } \\
\text { the soil vertically }\end{array}$ & 12 & No information & 7 \\
\hline 2 & $\begin{array}{l}\text { Howard } \\
\text { Rotalabour }\end{array}$ & $\begin{array}{l}\text { P.t.o.-driven rotary cultivator with angled straight blades } \\
\text { entering the soil vertically. } \\
\text { More information on: http://www.kongskilde.com/en-GB/ } \\
\text { Soil/dbProducts/Product.htm\%3fproductid\%3d364, } \\
\text { accessed 14th December } 2011\end{array}$ & 15 & 540 & 6 \\
\hline 2 & Dalbo & $\begin{array}{l}\text { Disc harrow with ground-driven angled discs. } \\
\text { Disc harrowing principles illustrated on: } \\
\text { http://www.kongskilde.com/en-GB/ } \\
\text { Soil/dbProducts/Product.htm\%3fproductid\%3d127, } \\
\text { accessed 14th December } 2011\end{array}$ & 17 & No information & 9.5 \\
\hline
\end{tabular}

2009-2011 at a target crop plant density of $350 \mathrm{pl} \mathrm{m}^{-2}: 160 \mathrm{~kg} \mathrm{ha}^{-1}$ sown on 15 April 2009; $150 \mathrm{~kg} \mathrm{ha}^{-1}$ sown on 21 April 2010; $145 \mathrm{~kg} \mathrm{ha}^{-1}$ sown on 7 April 2011. A harrow was used for seedbed preparation requiring $2-3$ passes for obtaining a proper seedbed. Degassed slurry from a biogas plant was applied just before seedbed harrowing each year using approximately $20 \mathrm{t} \mathrm{ha}^{-1}$ corresponding to approximately $120 \mathrm{~kg}$ total nitrogen ha $\mathrm{ha}^{-1}$ $\left(80 \mathrm{~kg} \mathrm{NH}_{4} \mathrm{ha}^{-1}\right), 24 \mathrm{~kg}$ phosphorus ha ${ }^{-1}$ and $38 \mathrm{~kg}_{\text {potassium ha }}{ }^{-1}$.

C. arvense growth was assessed in late June or the beginning of July in all three years 2009-2011. The assessment in 2009 was made to quantify the initial population level before the treatments were started. In 2009, the distribution of $C$. arvense shoots within the plots was assessed visually by dividing the entire plot into four zones: high, medium and low densities of shoots and a zone having no or very few shoots. The area of each zone was estimated from a hand-drawn map. Then one to three $0.5 \mathrm{~m}^{2}$ quadrates were placed randomly within each zone, the number of quadrates depending on the size of the zone and the uniformity of the C. arvense infestation. All above-ground weed material was cut at ground level and separated into two fractions: $C$. arvense and other weed species. Dry matter was obtained by drying the plant material in the oven for $24 \mathrm{~h}$ at $80{ }^{\circ} \mathrm{C}$. Finally, C. arvense biomass was estimated for each plot as an average of the density inside each zone weighed by zone area. However, owing to a general decline in the C. arvense population, it became too difficult to identify the zones in 2010 and 2011 and thus another assessment method was used. Eight $0.5 \mathrm{~m}^{2}$ quadrates were randomly scattered over each plot and the height of every single $C$. arvense shoot within the quadrate was measured. A linear relationship between $C$. arvense shoot biomass and shoot height was used as a reference for estimating aboveground biomass of $C$. arvense based on the measurements of shoot heights in the eight quadrates per plot; a method also used by Graglia et al. (2006). To obtain the relationship in 2010, five aboveground shoots of $C$. arvense from each of five height categories, e.g. of $0-10 \mathrm{~cm}, 11-20 \mathrm{~cm}$ and $21-30 \mathrm{~cm}$, etc., were harvested from the gross plot from each of four treatments (treatments 1, 2, 4 and 7 in Table 1 ) giving a total of 100 records. The dry weight of these shoots was determined after drying at $80{ }^{\circ} \mathrm{C}$ for $24 \mathrm{~h}$. The linear relationship was not affected by the treatments nor the height categories, meaning that a common relationship $(R=0.88)$ was used for the estimation of $C$. arvense biomass in 2010. In 2011, however, sampling was limited to five shoots from six height categories, in total 30 shoots, randomly selected within the whole experimental area. The number of records for the 2011-relationship $(R=0.92)$ was reduced because the relationship from 2010 and from a similar experiment (Holst et al., unpublished data) were not affected by the treatments. The occurrence of other perennial weeds in 2010 and 2011 was either recorded by counting plant numbers or by visually scoring their coverage of the eight quadrates per plot (scale $0-10$, where 10 is complete weed coverage of the quadrate). Counts and visual scores of $S$. arvensis, in particular, were also made later on in early August in both 2010 and 2011 and covered the whole plot. The counts or scores, however, only accounted for plant material (stems, flowers and leaves) that was visible above the crop canopy. In addition to the perennial species mentioned earlier, the principal flora of annual weed species consisted of Sinapis arvensis L., Chenopodium album L. and Bilderdykia convolvulus (L.) Dumort, among which Si. arvensis was by far the most predominant and the only annual species scored visually for its occurrence.

Each plot was combined for barley grain yield in August in all three years. Dry matter content was determined using a nearinfrared spectroscopy analyser (Infratec ${ }^{\mathrm{TM}} 1241$ Grain Analyzer, Foss A/S; Buchmann et al., 2001). Grain yields were adjusted to $85 \%$ dry matter content.

\subsection{Experiment 2}

The second experiment was conducted on a sandy soil at Jyndevad Experimental Station $\left(54^{\circ} 54^{\prime} \mathrm{N}, 9^{\circ} 07^{\prime} \mathrm{E}\right)$. A large population of T. farfara had developed by 2008 on the experimental area that had been cropped according to organic standards since 1996. Also $C$. arvense and E. repens had infested the area markedly. In summer 2008, the area was divided into three density categories according to the distribution of $T$. farfara. Nine stubble cultivation treatments were then randomised within each density category resulting in 27 treatments in total. Implements used are shown in Table 2. The treatments were started in autumn 2008, one week after harvest of 
spring barley. All treatments were conducted in two consecutive years and were applied at a 3-week interval in the autumn and for some treatments repeated again either in winter or the subsequent spring (Table 3). The goosefoot shares on Vibro Flex cut the soil over the full working width. Gross plot size was $6 \times 16 \mathrm{~m}$ of which $2.4 \times 10 \mathrm{~m}$ was used for assessments of weed and crop growth. Each gross plot was surrounded by $5 \mathrm{~m}$ wide discards that were mown during the growing season to prevent spreading of perennials between plots. Spring barley (variety Simba) was grown in 2008, 2009 and 2010, at a target crop plant density of $350 \mathrm{pl} \mathrm{m}^{-2}$ : $170 \mathrm{~kg} \mathrm{ha}^{-1}$ sown on 1 April 2008; $176 \mathrm{~kg} \mathrm{ha}^{-1}$ sown on 20 March 2009; $166 \mathrm{~kg} \mathrm{ha}^{-1}$ sown on 7 April 2010. The whole experimental area was rolled shortly before sowing using a heavy concrete roller to compact the soil after ploughing and cultivations of the previous year. Then the seedbed was prepared with a powered harrow. Slurry was applied just before seedbed preparation using: $12.2 \mathrm{t} \mathrm{ha}^{-1}$ corresponding to $70 \mathrm{~kg}$ total nitrogen $\mathrm{ha}^{-1}$ (50.7 kg NH $\mathrm{ha}^{-1}$ ), $12.2 \mathrm{~kg}$ phosphorus ha ${ }^{-1}$ and $36.6 \mathrm{~kg}$ potassium ha-1 in 2009; and $13.8 \mathrm{t} \mathrm{ha}^{-1}$ corresponding to $70 \mathrm{~kg}$ total nitrogen ha ${ }^{-1}\left(57.0 \mathrm{~kg} \mathrm{NH}_{4} \mathrm{ha}^{-1}\right), 15.3 \mathrm{~kg}$ phosphorus ha ${ }^{-1}$ and $38.7 \mathrm{~kg}$ potassium ha ${ }^{-1}$ in 2010 . An amount of nutrients similar to the 2009 application was applied in barley in 2008. Annual weeds were controlled in both years with a weed harrow: one pass preemergence and post-emergence, respectively. Manganese was applied around the tillering stage of barley using $750 \mathrm{~g} \mathrm{ha}^{-1}$ in 2009 and $1000 \mathrm{~g} \mathrm{ha}^{-1}$ in 2010.

Table 3

Treatment times for stubble cultivations and mouldboard ploughing (22 cm depth) in experiment 2 .

\begin{tabular}{|c|c|c|c|c|c|}
\hline \multirow{2}{*}{$\begin{array}{l}\text { Treatment } \\
\text { no. }\end{array}$} & \multirow{2}{*}{ Implement } & \multicolumn{3}{|c|}{ Treatment dates } & \multirow{2}{*}{$\begin{array}{l}\text { No. of passes } \\
(2008-2010)\end{array}$} \\
\hline & & 2008 & 2009 & 2010 & \\
\hline \multirow[t]{4}{*}{1} & Vibro Flex & 21 Aug & 14 Aug & & 2 \\
\hline & Howard Rotavator & 21 Aug & 14 Aug & & 4 \\
\hline & & 15 Sep & 8 Sep & & \\
\hline & Mouldboard ploughing & 19 Nov & 27 Nov & & 2 \\
\hline \multirow[t]{4}{*}{2} & Mouldboard ploughing & & $10 \mathrm{Mar}$ & $22 \mathrm{Mar}$ & 2 \\
\hline & Vibro Flex & 21 Aug & 14 Aug & & 2 \\
\hline & Howard Rotavator & 21 Aug & 14 Aug & & 4 \\
\hline & & 15 Sep & 8 Sep & & \\
\hline \multirow[t]{5}{*}{3} & Howard Rotavator & & $2 \mathrm{Mar}$ & 22 Mar & 2 \\
\hline & Mouldboard ploughing & & $10 \mathrm{Mar}$ & $22 \mathrm{Mar}$ & 2 \\
\hline & Vibro Flex & 21 Aug & 14 Aug & & 2 \\
\hline & Howard Rotavator & 21 Aug & 14 Aug & & 4 \\
\hline & & 15 Sep & 8 Sep & & \\
\hline \multirow[t]{4}{*}{4} & Howard Rotavator & & $2 \mathrm{Mar}$ & $22 \mathrm{Mar}$ & 2 \\
\hline & Mouldboard ploughing & & $10 \mathrm{Mar}$ & 22 Mar & 2 \\
\hline & Vibro Flex & 21 Aug & 14 Aug & & 4 \\
\hline & & 15 Sep & 8 Sep & & \\
\hline \multirow[t]{5}{*}{5} & Mouldboard ploughing & & $10 \mathrm{Mar}$ & $22 \mathrm{Mar}$ & 2 \\
\hline & Vibro Flex & 21 Aug & 14 Aug & & 2 \\
\hline & Howard Rotavator & 21 Aug & 14 Aug & & 6 \\
\hline & & 15 Sep & 8 Sep & & \\
\hline & & $29 \mathrm{Dec}$ & $15 \mathrm{Dec}$ & & \\
\hline \multirow[t]{3}{*}{6} & Mouldboard ploughing & & $10 \mathrm{Mar}$ & 22 Mar & 2 \\
\hline & Vibro Flex & 21 Aug & 14 Aug & & 4 \\
\hline & & 15 Sep & 8 Sep & & \\
\hline \multirow[t]{4}{*}{7} & Mouldboard ploughing & & $10 \mathrm{Mar}$ & $22 \mathrm{Mar}$ & 2 \\
\hline & Vibro Flex & 21 Aug & 14 Aug & & 2 \\
\hline & Dynadrive & 21 Aug & 14 Aug & & 5 \\
\hline & & $\begin{array}{l}15 \text { Sep } \\
\text { ( } 2 \text { pas.) }\end{array}$ & 8 Sep & & \\
\hline \multirow[t]{4}{*}{8} & Mouldboard ploughing & & $10 \mathrm{Mar}$ & $22 \mathrm{Mar}$ & 2 \\
\hline & Vibro Flex & 21 Aug & 14 Aug & & 2 \\
\hline & Howard Rotalabour & 21 Aug & 14 Aug & & 4 \\
\hline & & 15 Sep & 8 Sep & & \\
\hline \multirow[t]{4}{*}{9} & Mouldboard ploughing & & $10 \mathrm{Mar}$ & $22 \mathrm{Mar}$ & 2 \\
\hline & Vibro Flex & 21 Aug & 14 Aug & & 2 \\
\hline & Dalbo & 21 Aug & 14 Aug & & 4 \\
\hline & & 15 Sep & 8 Sep & & \\
\hline
\end{tabular}

Weed growth was assessed in late June or the beginning of July in 2008, 2009 and 2010, respectively. The assessment in 2008 was made to quantify the initial population level before the treatments were commenced. Three $0.5 \mathrm{~m}^{2}$ quadrates were randomly placed in each plot and all above-ground weed plant material within the quadrate was cut at grown level. Then the plant material was separated into six fractions: T. farfara, C. arvense, E. repens, Artemisia vulgaris L., other perennials (mainly Rumex spp. and Taraxacum officinale G.H. Weber ex Wiggers) and annual dicotyledonous weeds (predominantly Geranium ssp., Capsella bursa-pastoris (L.) Medik., Myosotis arvensis (L.) Hill, B. convolvulus, Stellaria media (L.) Vill. and C. album L.). Dry matter of each fraction was obtained by drying the plant material in the oven for $24 \mathrm{~h}$ at $80^{\circ} \mathrm{C}$.

Barley grain yields were obtained as described for experiment 1.

\subsection{Data analyses}

Weed biomass data were analysed using a general linear mixed model with normally distributed data (McCullagh and Nelder, 1989). Population growth rates $\left(r_{y} ; \mathrm{y}^{-1}\right)$ of $C$. arvense in experiment 1 and all perennial weeds combined in experiment 2 were calculated from one year to the next and were used as the response variable,

$r_{y}=\ln \left(\frac{N_{y+1}}{N_{y}}\right)$

where $N_{y}$ is weed biomass in year $y$ and $N_{y+1}$ is weed biomass in year $y+1$ where $y=2009$ and 2010 for the data in experiment 1 ( $n=105)$ and $y=2008$ and 2009 for the data in experiment 2 $(n=81)$. Fixed effects of the full model for both experiments included the categorical variables year and treatment and the covariate $N_{y}$ including all interactions. A significant effect of plant density $N_{y}$ would imply that the population followed a densitydependent, logistic growth pattern. Block effects and the interaction between year and block were included as random effects in the models.

The conversion of population density to growth rate removed the serial autocorrelation in the data for both experiments. The validity of this was checked by testing the Pearson correlation coefficient $R$ between all pair-wise $r_{y}$ and $r_{y+1}$ values. Half the lowest biomass-value $>0$ in the dataset was added to all $N_{y}$ and $N_{y+1}$ values because values where $N_{y}=0$ and/or $N_{y+1}=0$ appeared in the datasets. For example, $0.29 \mathrm{~g} \mathrm{~m}^{-2}$ was added to the $C$. arvense biomass data in experiment 1 and $0.13 \mathrm{~g} \mathrm{~m}^{-2}$ to total perennial weed biomass data in experiment 2 . There was generally no change in the population when $N_{y}=0$ but when $N_{y}>0$ and $N_{y+1}=0$, the adjustments ensured that such clear effects were taken into account in the analyses. This was especially necessary in experiment 1 as a result of strong treatment effects. Generally the adjustments caused no outliers or obscure growth rate values.

Grain yields in seasons 2009, 2010 and 2011 for experiment $1(n=105)$ and seasons 2008, 2009 and 2010 for experiment $2(n=81)$ were regressed on the above-ground weed biomass; C. arvense biomass only in experiment 1 and total weed biomass (perennials plus annuals) in experiment 2. The full models also included year and treatment as categorical variables.

The parameters of the models were estimated using residual likelihood estimations. Calculations were made using the MIXED procedure of SAS (SAS release 9.13), and means were calculated as least square means (LSM). Models were reduced by excluding nonsignificant effects based on likelihood ratio tests and Akaike's information criterion (Akaike, 1974). The denominator degrees of freedom (DDF) in $F$-tests and $t$-tests for mean separations were calculated according to Kenward and Roger (1997). 


\section{Results}

\subsection{Experiment 1}

The model describing the growth rates for the two periods 2009-2010 and 2010-2011 was successively reduced to only contain a general effect of the covariate $N_{y}(P=0.0031)$ and the main effect of treatment $(P=0.0743)$. The model estimated a common slope of $-0.0032 \pm 0.00103$ s.e. and an intercept of $-2.23 \pm 0.464$ s.e. across all treatments and years. There was no significant correlation between $r_{y}$ and $r_{y+1}$ values $(R=0.217$, $P=0.2101, n=35)$, justifying the use of the model. Although the main effect of treatment was only close to significant at the 5\%level, pair-wise comparisons of the treatments did reveal some differences (Table 4). All treatments caused a significant annual reduction of the $C$. arvense population but differences among treatments were relatively small with sole autumn ploughing resulting in the lowest reduction. The accumulated reductions of the initial population reached $97.5-99.4 \%$ in 2011 for treatments $2-7$.

The occurrence of $S$. arvensis was negligible in 2009 but large enough for making statistical analyses in 2010 and 2011 (Table 5). The perennial had proliferated from 2009 to 2011, contrarily to C. arvense, and was most numerous in the sole plough treatments in 2011.

Neither year nor treatment affected the occurrence of the annual species Si. arvensis.

Biomass of $C$. arvense affected grain yield in 2009 only $(P=0.001)$ with a slope of $-0.0013 \pm 0.00034$ s.e. and an intercept of $2.19 \pm 0.081$ s.e. $\mathrm{t} \mathrm{ha}^{-1}$. Only year influenced $(P=0.0029)$ the variation in yields in subsequent years with yields averaging $4.34 \pm 0.081$ s.e. $\mathrm{t} \mathrm{ha}^{-1}$ in 2010 and $3.29 \pm 0.082$ s.e. $\mathrm{t} \mathrm{ha}^{-1}$ in 2011.

\subsection{Experiment 2}

Treatment effects on weed biomass were analysed for perennial weed biomass in total, $T$. farfara and $C$. arvense, respectively. Only the main effects listed in Table 6 significantly explained the variation in the dataset. Again the correlation coefficients between $r_{y}$ and $r_{y+1}$ values were not significant (e.g. $R=0.210, P=0.293, n=27$ for perennial weed biomass in total), which excluded the need for auto-correlation in the analysis. Treatment 4 with a mixture of tinebased and rotating weeding devices had the lowest control efficacy while differences among the other treatments were small. However, treatment 6 with pure tine-based stubble cultivations was almost significantly weaker than the p.t.o.-driven tools when contrasting treatment 6 with treatments $1,2,3,5$ and 8 $(P=0.0586)$. The accumulated effect of the treatments of two years

\section{Table 4}

Initial biomass of $C$. arvense in experiment 1 in 2009 shown as means with standard errors in parentheses. Growth rates $r$ for each treatment is shown as least squares means (LSM) and the \% annual reduction of the population. The probability of $r \neq 0$ denotes the significance of population changes. The maximum standard error of difference (SED) between $r$-LSMs is shown in italics.

\begin{tabular}{lllrl}
\hline Treatment & $\begin{array}{l}\text { Biomass 2009 } \\
\left(\mathrm{g} \mathrm{m}^{-2}\right)\end{array}$ & $\begin{array}{l}\text { Growth rates } r \\
(\mathrm{LSM})\end{array}$ & $\begin{array}{l}\text { Probt. } \\
r \neq 0\end{array}$ & $\begin{array}{l}\text { \% Reduction } \\
\text { year }^{-1}\end{array}$ \\
\hline 1 & $216(97.0)$ & $-1.18 \mathrm{a}$ & 0.0209 & 69.3 \\
2 & $120(28.3)$ & $-1.84 \mathrm{ab}$ & 0.0010 & 84.1 \\
3 & $179(87.6)$ & $-1.96 \mathrm{ab}$ & 0.0006 & 85.9 \\
4 & $273(116.4)$ & $-1.95 \mathrm{ab}$ & 0.0007 & 85.8 \\
5 & $192(44.9)$ & $-2.49 \mathrm{~b}$ & $<0.0001$ & 91.7 \\
6 & $162(38.1)$ & $-2.58 \mathrm{~b}$ & $<0.0001$ & 92.4 \\
7 & $150(66.4)$ & $-2.55 \mathrm{~b}$ & $<0.0001$ & 92.2 \\
SED & & 0.507 & & \\
\hline
\end{tabular}

Values with the same letters are not significantly different at the 5\%-level.
Table 5

Visual scores (\% coverage) of Sonchus arvensis in experiment 1 in August 2010 and shoot number in August 2011 shown as least square means (LSM) with both transformed and back transformed values. The maximum standard error of difference (SED) between LSMs is shown in italics.

\begin{tabular}{|c|c|c|c|c|}
\hline \multirow[t]{2}{*}{$\begin{array}{l}\text { Treatment } \\
\text { no. }\end{array}$} & \multicolumn{2}{|c|}{ 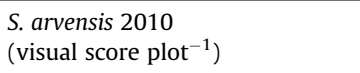 } & \multicolumn{2}{|c|}{$\begin{array}{l}\text { S. arvensis } 2011 \\
\left(\text { No. shoots } \text { plot }^{-1}\right)\end{array}$} \\
\hline & Log-transformed & $\begin{array}{l}\text { Back } \\
\text { transformed }\end{array}$ & $\begin{array}{l}y^{0.5} \\
\text { transformed }\end{array}$ & $\begin{array}{l}\text { Back } \\
\text { transformed }\end{array}$ \\
\hline 1 & $1.20 \mathrm{a}$ & 2.3 & $5.42 \mathrm{a}$ & 29.4 \\
\hline 2 & $0.64 \mathrm{ab}$ & 0.9 & $4.01 \mathrm{ab}$ & 16.1 \\
\hline 3 & $0.14 \mathrm{~b}$ & 0.2 & $0.60 \mathrm{c}$ & 0.4 \\
\hline 4 & $0.76 \mathrm{ab}$ & 1.1 & $2.28 \mathrm{bc}$ & 5.2 \\
\hline 5 & $0.72 \mathrm{ab}$ & 1.1 & $1.97 \mathrm{c}$ & 3.9 \\
\hline 6 & $0.14 \mathrm{~b}$ & 0.2 & $1.28 \mathrm{c}$ & 1.6 \\
\hline 7 & $0.42 \mathrm{~b}$ & 0.5 & $2.18 \mathrm{bc}$ & 4.8 \\
\hline SED & 0.388 & & 1.038 & \\
\hline
\end{tabular}

Values with the same letters are not significantly different at the 5\%-level.

in a row averaged $98.3 \%$ for treatments $1-3,5$ and $7-9$. No clear distinction in weed control efficacy against $T$. farfara and $C$. arvense were found among the treatments, but $T$. farfara declined more from 2009-2010 as compared to 2008-2009.

Biomass of annual dicotyledonous species in total differed between years $(P<0.001)$ averaging $118.76 \pm 8.801$ s.e. $\mathrm{g} \mathrm{m}^{-2}$ in $2008,47.59 \pm 4.711$ s.e. $\mathrm{g} \mathrm{m}^{-2}$ in 2009 and $65.88 \pm 4.731$ s.e. $\mathrm{g} \mathrm{m}^{-2}$ in 2010. A significant main effect of treatment $(P=0.0247)$ was also found showing that treatments 1,2 and 6 had slightly less annual weed biomass.

The covariate total weed biomass (perennials plus annuals) had no effect on crop yield in the regression-analyses. Yields were only affected by year $(P<0.001)$ averaging $2.01 \pm 0.093$ s.e. $\mathrm{t} \mathrm{ha}^{-1}$ in $2008,3.53 \pm 0.093$ s.e. $\mathrm{t} \mathrm{ha}^{-1}$ in 2009 and $1.81 \pm 0.093$ s.e. $\mathrm{t} \mathrm{ha}^{-1}$ in 2010.

\section{Discussion and conclusions}

Mouldboard ploughing in spring only tended to affect $C$. arvense more than autumn ploughing in experiment 1 , and treatments 1 and 2 resulted in the same effects in experiment 2. Ploughing in spring is expected to interrupt the growth of early sprouting from root or rhizome fragments, but apparently not to an extent of any importance. Decisions on ploughing in spring instead of autumn should not be made according to the need for perennial weed control according to our findings and thus hypothesis i. cannot be supported.

Generally, autumn tillage only gave minor additional effects compared to sole mouldboard ploughing with only treatments 5 and 6 differing significantly from autumn ploughing but not from spring ploughing in experiment 1 . All the treatments suppressed $C$. arvense growth strongly, leading to almost eradication following treatments conducted in two consecutive years. Other studies have demonstrated more variable effects of stubble cultivation plus mouldboard ploughing, which could not be explained unambiguously by soil type, implement type, timing of treatments or other factors (Brandsæter et al., 2011b; Olsen, 2011; Holst et al., unpublished data). Factors, such as inter-competition within $C$. arvense patches and harsh winters in 2010 and 2011 affecting spatial C. arvense shoot dynamics, might have contributed to this marked decline of $C$. arvense in our study. However, an untreated control would have been needed to determine whether such a general decline of the population was present.

Contrary to hypothesis ii., cultivation depth had minor importance in experiment 1 . Especially ploughing, and maybe to a smaller extent the exhaustion of the root system caused by repeated 
Table 6

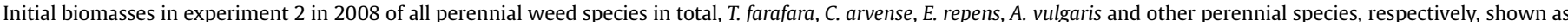

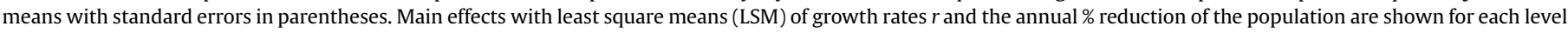

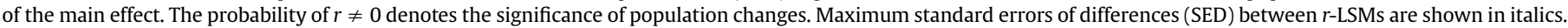
SE is the standard error of the estimate for $r$-LSM for C. arvense in the 2008-2009 course only.

\begin{tabular}{|c|c|c|c|c|c|}
\hline Species & Main effect & Biomass $2008\left(\mathrm{~g} \mathrm{~m}^{-2}\right)$ & Growth rates $r$ & Probt. $r \neq 0$ & \% Reduction year ${ }^{-1}$ \\
\hline \multirow[t]{11}{*}{ Total } & Treat. $(P=0.0228)$ & & & & \\
\hline & 1 & $150(25.5)$ & $-1.95 \mathrm{a}$ & $<0.0001$ & 85.8 \\
\hline & 2 & $172(31.2)$ & $-2.20 \mathrm{a}$ & $<0.0001$ & 88.9 \\
\hline & 3 & $61(29.7)$ & $-2.14 \mathrm{a}$ & $<0.0001$ & 88.2 \\
\hline & 4 & $137(44.5)$ & $-0.73 b$ & 0.0375 & 51.8 \\
\hline & 5 & $86(4.0)$ & $-2.41 \mathrm{a}$ & $<0.0001$ & 91.0 \\
\hline & 6 & $107(18.6)$ & $-1.52 \mathrm{ab}$ & $<0.0001$ & 78.1 \\
\hline & 7 & $92(6.5)$ & $-1.62 a b$ & $<0.0001$ & 80.2 \\
\hline & 8 & $198(75.8)$ & $-2.40 \mathrm{a}$ & $<0.0001$ & 90.9 \\
\hline & 9 & $157(42.9)$ & $-1.81 \mathrm{a}$ & $<0.0001$ & 83.6 \\
\hline & SED & & 0.468 & & \\
\hline \multirow[t]{4}{*}{ T. farfara } & Year $(P=0.0526)$ & & & & \\
\hline & $2008-2009$ & $46(6.9)$ & $-1.14 \mathrm{a}$ & 0.0528 & 68.0 \\
\hline & 2009-2010 & & $-1.82 \mathrm{~b}$ & 0.0153 & 83.8 \\
\hline & SED & & 0.339 & & \\
\hline \multirow[t]{2}{*}{ C. arvense } & $2008-2009^{a}$ & $43(7.8)$ & -1.46 & $<0.0060$ & 76.8 \\
\hline & $S E$ & & 0.378 & & \\
\hline E. repens & $\mathrm{b}$ & $18(5.2)$ & - & - & - \\
\hline A. vulgaris & b & $17(5.8)$ & - & - & - \\
\hline Other & b & $5(1.9)$ & - & - & - \\
\hline
\end{tabular}

Values with the same letters are not significantly different at the $5 \%$-level.

a Not estimated for 2009-2010 due to little or absent biomass in 2010

b Not estimated due to little or absent biomass in 2009 and 2010.

cultivation, may have eclipsed the impact of cultivation depth. Pekrun and Claupein (2004) also found that cultivation depth and implement type were of minor importance for autumn cultivation against $C$. arvense. More importantly, autumn cultivation had to be ended by inverting tillage to $20-25 \mathrm{~cm}$ for obtaining high effectiveness.

S. arvensis proliferated during the experimental period despite ploughing. However, post-harvest cultivation hampered its proliferation as suggested by Anbari et al. (2011) and Vanhala et al. (2006). Seeds of S. arvensis are wind-disseminated and may easily establish on new land, if tillage is reduced (Froud-Williams et al., 1983). The root system expands rapidly in a year (Lemna and Messersmith, 1990), especially in organic crops with limited competitive abilities. Apparently, roots large enough to withstand ploughing can be produced, if growth is not disturbed in the stubble period.

The p.t.o.-driven tools (Howard Rotavator and Rotalabour) in experiment 2 tended to diminish the mixed stand of perennials more strongly than the tine-based cultivator (Vibro Flex) but the total number of passes was also higher in treatments 1, 2, 3, 5 and 8 (Table 3 ). This partly supports hypothesis iii. but only for the tinebased tool, as the effectiveness of the disc-based implement (Dalbo) was almost similar to the p.t.o.-driven ones. Rotating implements normally fragment rhizomes into shorter pieces than tine-based implements (Permin, 1973). Repeating the treatments would eventually lead to substantial exhaustion and weakening of the vegetative propagules or even mortality if re-sprouting is taking place. Supplementing the tillage treatments in autumn by further passes in winter or spring did not improve effectiveness, meaning that hypothesis iv. cannot be supported. This is probably due to the higher presence of $C$. arvense and $T$. farfara, as opposed to E. repens, in experiment 2 . The two dicotyledonous perennials are known to grow less readily in late summer and autumn than E. repens (Brandsæter et al., 2010; Tørresen et al., 2010). Depleting the carbohydrates in the roots of $C$. arvense and rhizomes of $T$. farfara is probably less pronounced as compared to E. repens. Nevertheless, experiment 2 suggests that intensive tillage between crops conducted in two consecutive years may have general application on sandy soils against perennial weeds despite the presence of species with different biologies. Autumn tillage interrupts the translocation of carbohydrates to roots and rhizomes happening from midsummer until late autumn (Nkurunziza and Streibig, 2011). Vegetative propagules are also fragmented into shorter pieces, exposed to desiccation, if uprooted, and depleted for carbohydrates depending on their readiness to sprout after cultivation. The sum of these effects can result in a substantial reduction of a mixed stand as shown in experiment 2 .

The high treatment effects in experiment 1 lowered the population of $C$. arvense to such low levels that the variation in $C$. arvense biomass did not affect crop yield as regressions were non-significant. Graglia et al. (2006) also found that $C$. arvense biomasses in the range of $0-60 \mathrm{~g} \mathrm{~m}^{-2}$ did not correlate significantly to spring barley grain yield. Crop yields were also not significantly affected by the variation in total weed biomass in experiment 2 , probably because the span in biomasses was too small for achieving significant correlations. The inclusion of an untreated control in both experiments 1 and 2 might have revealed the yield benefits of tillage for the control of perennials. However, non-inversion tillage or no tillage was not prioritised in this study because such practises have very little employment in European organic farming for various reasons (Peigné et al., 2007). For the preservation of crop yield in this study, the simplest treatments, mouldboard ploughing only in experiment 1 and tine cultivation (treatment no. 6) in experiment 2, appear most cost-effective but may not provide longer lasting control. However, the very low yield level in 2010 in experiment 2 might be attributable to the treatments. All treatments loosened and aerated the sandy soil substantially, presumably resulting in manganese deficiency (Norwell, 1988) despite rolling and application of manganese. This assumption is only based on the appearance of the barley crop that looked very pale from early on in the growing season 2010. Anyway this is an aspect that needs consideration before making wider recommendations on the control of perennials. Whether manganese deficiency played a role for the likewise low yield level in 2008 was also not clear.

In conclusion, intensive post-harvest cultivation followed by deep inverting tillage can strongly diminish a severe weed problem 
consisting of multiple perennial species on sandy soils. The applicability of the strategies on other soil types needs verification. Moreover, the strategies are intensive, relatively costly and do not comply with optimal nutrient management in organic cropping. Consequently, intensive autumn cultivation should only be applied where a problem with perennial weeds is uncontrollable by other means and should then only be applied on limited areas, if possible.

\section{Acknowledgements}

We thank the Danish Ministry of Food, Agriculture and Fisheries and the International Centre for Research in Organic Food Systems for funding this research; and technicians Henning C. Thomsen, Lena Christensen, Eugene Driessen and Karen Bjørn Heinager for technical assistance.

\section{References}

Akaike, H., 1974. A new look at the statistical model identification. Trans. Automatic Control 19, 716-723.

Alrøe, H.F., Halberg, N., 2008. Udvikling, vækst og integritet i den danske økologisektor. Vidensyntese. ICROFS Rapport Nr 1. 2008

Anbari, S., Lundkvist, A., Verwijst, T., 2011. Sprouting and shoot development of Sonchus arvensis in relation to initial root size. Weed Res. 51, 142-150.

Ascard, J., Hatcher, P.E., Melander, B., Upadhyaya, M.K., 2007. 10 Thermal weed control. In: Upadhyaya, M.K., Blackshaw, R.E. (Eds.), Non-Chemical Weed Management: Principles, Concepts and Technology. CAB International, Wallingford, UK, pp. 155-175. www.cabi.org.

Bond, W., Grundy, A.C., . Non-chemical weed management in organic farming systems. Weed Res. 41, 383-405.

Brandsæter, L.O., Fogelfors, H., Fykse, H., Graglia, E., Jensen, R.K., Melander, B., Salonen, J., Vanhala, P., 2010. Seasonal restrictions of bud growth on roots of Cirsium arvense and Sonchus arvensis and rhizomes of Elymus repens. Weed Res. 50, 102-109.

Brandsæter, L.O., Bakken, A.K., Mangerud, K., Riley, H., Eltun, R., Fykse, H., 2011a. Effects of tractor weight, wheel placement and depth of ploughing on the infestation with perennial weeds in organic farmed cereals. Europ. J. Agron. 34, 239-246.

Brandsæter, L.O., Goul Thomsen, M., Wærnhus, K., Fykse, H., 2011b. Effects of repeated clover undersowing in spring cereals and stubble treatments in autumn on Elymus repens, Sonchus arvensis and Cirsium arvense. Crop Prot. 32, 104-110.

Buchmann, N.B., Josefsson, H., Cowe, I.A., 2001. Performance of European artificial neural network (ANN) calibration for moisture and protein in cereals using the Danish near-infrared transmission (NIT) network. Cereal Chem. 78, 572-577.

Donald, W.W., 1990. Management and control of Canada Thistle (Cirsium arvense). Rev. Weed Sci. 5, 193-250.

Froud-Williams, R.J., Drennan, D.S.H., Chancellor, R.J., 1983. Influence of cultivation regime on weed floras of arable cropping systems. J. Appl. Ecol. 20, 187-197.
Graglia, E., Melander, B., Jensen, R.K., 2006. Mechanical and cultural strategies to control Cirsium arvense in organic arable cropping systems. Weed Res. 46, 304-312.

Håkansson, S., 1969. Experiments with Agropyron repens (L.) Beauv. 4. Response to burial and defoliation repeated with different intervals. Lantbrukshögskolans Annaler 35, 61-78.

Kenward, M.G., Roger, J.H., 1997. Small sample inference for fixed effects from restricted maximum likelihood. Biometrics 53, 983-997.

Lemna, W.K., Messersmith, C.G., 1990. The biology of Canadian weeds. 94. Sonchus arvensis L. Can. J. Pl. Sci. 70, 509-532.

McCullagh, P., Nelder, J.A., 1989. Generalized Linear Models, second ed. Chapman and Hall, London.

Melander, B., 1994. Modelling the effects of Elymus repens (L.) Gould competition on yield of cereals, peas and oilseed rape. Weed Res. 34, 99-108.

Melander, B., Rasmussen, I.A., Barberi, P., 2005. Integrating physical and cultural methods of weed control - examples from European research. Weed Sci. 53, 369-381.

Melander, B., Mathiassen, S.K., Nørremark, M., Kristensen, E.F., Kristensen, J.K., Kristensen, K., 2011. Physical destruction of the sprouting ability of Elytrigia repens rhizome buds. Weed Res. 51, 469-477.

Nkurunziza, L., Streibig, J.C., 2011. Carbohydrate dynamics in roots and rhizomes of Cirsium arvense and Tussilago farfara. Weed Res. 51, 461-468.

Norwell, W., 1988. Inorganic reactions of manganese in soils. In: Graham, R. Hannan, R., Uren, N. (Eds.), Manganese in Soils and Plants. Kluwer Academic Publishers, Dordrecht, pp. 155-173.

Olsen, L.E., 2011. Strategier til regulering af rodukrudt. In: Proceedings Plantekongress 2011 - produktion, planter og miljø, Herning, Denmark pp. $172-174$.

Peigné, J., Ball, B.C., Roger-Estrade, J., David, C., 2007. Is conservation tillage suitable for organic farming? A review. Soil Use Manage. 23, 129-144.

Pekrun, C., Claupein, W., 2004. The effect of stubble tillage and primary tillage on population dynamics of Canada Thistle (Cirsium arvense) in organic farming. J. Plant Dis. Protect. (Special Issue XIX), 483-490.

Pekrun, C., Claupein, W., 2006. The implication of stubble tillage for weed population dynamics in organic farming. Weed Res. 46, 414-423.

Permin, O., 1973. Virkning på den vegetative formering hos alm. kvik (Agropyron repens) når de underjordiske udløbere bliver skåret i stykker. (The effect of cutting rhizomes into pieces of different lengths on the growth of Agropyron repens. With English summary). Tidsskrift for Planteavl 77, 357-369.

Rasmussen, I.A., Askegaard, M., Olesen, J.E., Kristensen, K., 2006. Effects on weeds of management in newly converted organic crop rotations in Denmark. Agr. Ecosyst. Environ. 113, 184-195.

Salonen, J., Hyvönen, T., Jalli, H., 2011. Composition of weed flora in spring cereals in Finland - a fourth study. Agri. Food Sci. 20, 245-261.

Turner, R.J., Davies, G., Moore, H., Grundy, A.C., Mead, A., 2007. Organic weed management: a review of the current UK farmer perspective. Crop Prot. 26, $377-382$.

Tørresen, K.S., Fykse, H., Rafoss, T., 2010. Autumn growth of Elytrigia repens, Cirsium arvense and Sonchus arvensis at high latitudes in an outdoor pot experiment. Weed Res. 50, 353-363.

Vanhala, P., Lötjönen, T., Hurme, T., Salonen, J., 2006. Managing Sonchus arvensis using mechanical and cultural methods. Agri. Food Sci. 15, 444-458.

Zaller, J.G., 2004. Ecology and non-chemical control of Rumex crispus and R. obtusifolius (Polygonaceae): a review. Weed Res. 44, 414-432. 